To find out the effect of the disease the two groups were compared in the various Binet tests, the frequency and percentage of each group passing the given tests being tabulated and the percentage of deterioration on each test calculated.

On the hypothesis that the ability to pass a given test is cortically localized, a randomly distributed deterioration would be expected. Such was not the case. The experimental findings supported the hypothesis that intelligence is a function of the whole brain, against the hypothesis of specific localization.

\title{
LONDON'S WATER DURING 1938
}

$\mathrm{T}$ HE recently issued report of the Metropolitan Water Board* tells of the unceasing supervision exercised over London's water supply during 1938. The total output from the Board's works was 111,438 million gallons, a slight increase over the previous high record of 1937, the average daily supply to consumers being $312 \cdot 77$ million gallons, of which 65 per cent was derived from the Thames.

Some 50,000 samples were analysed during the year, of which about 30,000 were routine bacteriological, and 4,700 routine chomical, examinations, the main purpose of which is to determine that all the processes-storage, filtration, purification, distribution-are working satisfactorily so as to ensure a pure and safe supply to consumers. Based upon the Bact. coli test, 99 per cent of all samples were of first-class quality (absence of Bact. coli from $100 \mathrm{ml}$.) -a highly satisfactory record.

Of researches conducted in the Board's Laboratories, much attention has been directed to improving the Bact. coli test, and the method for isolating coliform organisms when present, for the purpose of differentiating the type. New procedures were also investigated for improving the method of isolation of Clostridium Welchii and the Streptococcus organisms that are sometimes of service for assessment of the potability of a water.

The occurrence of Bact. paratyphosum B, a microbe that causes a form of enteric fever, in Epping sewage has been noted since 1931. This specific organism is still present in the sewage, in fact was somewhat more numerous than it was in 1937, and as a precaution chlorination of the effluent has now been established as a permanent measure. Investigations on improved methods for the isolation of this organism are in progress.

Complaints are sometimes received concerning the

* Metropolitan Water Board. Thirty-third Annual Report on The Results of the Bacteriological, Chemical and Biological Examinations of London Waters for the Twelve Months ended 31st December, 1938. By Lt.Col. E. F. W. Mackenzie, Director of Water Examination. Metropolitan Water Board. (P. S. King and Son, Ltd., 14 Great Smith Street, Westminster.) $10 s .6 d$. taste of the water, and no less than 11,360 'taste' tests were carried out during the year by the expert tasters of the Board's staff. Complaints of taste are generally attributable to some defect at the works, the commonest being an overdose of chlorine. Earthy or musty tastes result from decomposition of, or fungoid growths in, filter bed skins during hot weather, and characteristic tastes are produced by decomposing plankton. In one instance, a musty taste occurred in the water drawn from the cold water tap in a kitchen, and was traced to two species of fungi growing in the tap. Organisms belonging to the Actinomyces are capable of producing earthy tastes, and this subject is under investigation.

Certain algæ and diatoms are subject to periods of sudden excessive growth, and are liable to cause trouble in reservoirs and filter beds. Thus, it was reported that a 'brown' growth had arisen in one of the reservoirs, and microscopical examination showed that this was caused by excessive growth of a diatom, Stephanodiscus Hantzschii, which was clogging the secondary filter beds. By treatment with alum this trouble was overcome. Investigations are being carried out in the Biological Section with the view of ascertaining the cause of these fluctuations in the number of the algal and other living forms in the water; they may depend upon peculiar variations in the silica, phosphates and other mineral constituents of the water which are known to take place at certain seasons of the year. An account is given of the appearance in a reservoir of Oscillatoria rubescens, a blue-green alga, and of the chemical conditions prevailing. In August when this organism became very numerous, $p H$ values were higher, temporary hardness was lower, and concentrations of $\mathrm{PO}_{4}$ were rising rapidly to a very high level compared with March, when the organism was scanty.

Notes are given on the occurrence of certain rare Copepods and other forms of microscopic life, numerous tables are included, and the report is illustrated with several excellent plates.

\section{ECONOMICS OF WAR COSTS}

$\mathrm{T}$ HE problem of paying for the War is discussed in an Oxford Pamphlet on World Affairs (Oxford : Clarendon Press. 3d. net) by G. Crowther and a broadsheet issued by Political and Economic Planning (P E P), which have both appeared under that title. The real problems of paying for the War, the broadsheet points out, are economic, political and psychological; for the limits of war effort are not financial but social, psychological and economic. The size of the output of war material depends on the willingness of people to work harder and make their capital resources last longer, and above all, on the way they react to reductions in their standards of life. The methods of financing the War are vitally. important, since they determine the distribution of its cost between different groups of people and may 
have a profound effect upon the distribution of in. come after the War, The best method can only be decided after a careful examination of social claims and resistances, and once the method is decided financial technique can be used to implement policy.

The P E P broadsheet, taking the national income of Great Britain as $£ 5,700$ millions, and the current national expenditure at more than $£ 2,500$ millions, points out that the increased revenue must be drawn from increased production, the use of overseas assets and the diversion of output. Mainly it will be a burden for the present. Diversion of output from capital maintenance is estimated as offering savings from $£ 300$ to $£ 500$ millions, while for the diversion of resources from the production of goods for private consumption varying estimates are given. The four main methods by which the Government can gain control over the resources which it needs are taxation, borrowing, through the medium of the price mechanism and by direct Government control.

In regard to taxation, the broadsheet points out that the bulk of additional income tax revenue must come from the middle incomes, where its incidence is comparatively light, and the importance of devising a comprehensive family allowance scheme is stressed. Reviewing other taxation possibilities, the scope for a tax on luxuries is indicated; the inevitable heavy taxation of those with low incomes will be resented unless the Government makes it quite clear that those who are comfortably or luxuriously off are being taxed in earnest. Discussing Mr. Keynes' proposals for forced saving by paying a proportion of all wages and salaries in the form of a blocked deposit not available for spending until after the War, the broadsheet points out that the scheme offers a means of preventing standards of living from rising, or of reducing them without incurring major political opposition. Further research into the limits of the voluntary type of saving is also required.

In regard to borrowing, the raising of loans directly from the public is not inflationary, but borrowing from the banks is almost bound to be inflationary. This is the third method by which the Government can gain control of the requisite resources, and both the broadsheet and Mr. Crowther point out the objections to inflation. Mr. Crowther urges that we should first concentrate on raising taxation to the highest supportable level on rich and poor alike. We should then see what could be done by rationing to increase the genuine savings that can be borrowed. Only when we have exhausted these deliberate and scientifically planned devices should we turn to the haphazard, incalculable and inequitable method of inflation. Certain measures of Government control over the economy are an indispensable adjunct to inflation, such as price control and its corollary rationing.

Mr. Crowther argues that the fundamental task of war finance is to transfer resources from consumption to the purposes of war, and he insists that, while totalitarian war cannot be financed entirely out of taxation, the only taxes likely to bring in sums substantial enough to contribute to avoidance of inflation are not confiscatory taxes on the rich or fancy taxes on profiteers, but plain honest taxes that hurt plain honest people. Moreover, since the real economic necessity of war is to reduce consumption, even after the ordinary man has paid his taxes, his consumption must be further restricted, either by voluntarily or compulsorily increasing his savings or through the cost of living rising against him.

\section{SEVENTY YEARS AGO}

\author{
NATURE, vol. 2, May 26, I870
}

THE Admiralty have acceded to the request of the Royal Society by again placing Her Majesty's surveying steam-vessel the Porcupine at their disposal for another deep-sea expedition. A photometric apparatus has been contrived by Mr. Siemens to ascertain the depth to which solar light penetrates the sea.

The Duke of Devonshire, the Marquis of Lansdowne, Sir John Lubbock [Lord Avebury], Sir James Kay-Shuttleworth, Bernard Samuelson, Dr. W. Sharpey, Prof. T. H. Huxley, Prof. W. A. Miller and Prof. [Sir] G. G. Stokes have been appointed to make inquiry with regard to Scientific Instruction and the Advancement of Science, and to inquire what aid thereto is derived from grants voted by Parliament or from university and college endowments, and whether such aid could be made more effectual.

\section{APPOINTMENTS VACANT}

APPLICATIONs are invited for the following appointments on or before the dates mentioned:

Temporary Lecturer (WOMan) in Education and PSYchology $\rightarrow$ The Principal, Municipal Training College, Cottingham Road, Hul (May 30).

Lecturer in Mathematics, and a SENIoR Mrstress for the Day School-The Clerk to the Governors, South-East Essex Technical College and School of Art, Longbridge Road, Dagenham (May 31).

HEAD OF THE WOMEN's DEPARTMFNT of the Blackpool Technical College-The Director of Education, Education offices, Stanley Buildings, Blackpool (May 31).

Head of the Chemistry Department--The Principal, Municipal Technical College, Hopwood Lane, Halifax (May 31).

A Representative to superintend and co-ordinate the work of the British Council in Bulgaria, Rumania and Yugoslavia-The British Council, 3 Hanover Street, W.1 (June 1).

Two TEACHERS (MEN) OF ENGLish for Yugoslav-British Institute Belgrade-The British Council, 3 Hanover Street, W.1 (quoting 'Belgrade') (June 1).

Lecturar in BIOLogY-The Secretary, Technical College, Sunderand (June 3).

Lecturer (MALE) of PHysics-The Clerk to the Governors, Northern Polytechnic, Holloway, N.7 (June 3)

Assistant Woman Graduate For COMmercial Geography in the Schools of Technology. Art and Commerce, Oxford-The Chief Education Officer, Education Offices, 77 George Street, Oxford (June 4).

Male Lecturer iv English at Oporto University, Portugal-The British Council, 3 Hanover Street, W.1 (quoting 'Portugal') (June 5).

HEAD OF THE SCHOOL OF ARCHITECTURE AND BUILDING-The Registrar, School of Architecture and Building, College of Arts and Crafts, Leicester (June 7)

INSPECTOR, Southern Education-The Controller, Sudan GovernINSPECTOR, Southern Education-The Controller, Sudan Government London Office, Wellington House, Buckingham

MathrmaticaL TUTOR in the Khartoum Secondary School-The Controller, Sudan Government London Office, Wellington House, Buckingham Gate, S.W.1 (quoting 'Mathematical Tutor') (June 15).

LECTURER in CHemistry in the School of Science, KhartoumThe Controller Sudan Government London Office, Wellington House, Buckingam , Sate, S.W. (quoting 'Lecturer in Chemistry') (June 15). LECTURER IN ELECTRICAL ENGINEERING, and a LECTURER IN
MECHANICAL ENGINEERING, at the School of Engineering, Khartoum MECHANICAL ENGINEERING, at the School of Engineering, Khartoum The controller, Sudate, S.W.1 (quoting 'Lecturer in Electrical/or Mechanical Engineering') (June 15).

HEAD OF THE CHEMISTRY DEPARTMENT-The Clerk to the Governors, Technical College, Normanton Road, Derby (June 15).

Curator of the MUSedi aNd ART Gallery-The Town Clerk,

Town Hall, Leicester (endorsed 'Curator') (June 17).

CHIFF FISHERres OFFICER, Palestine-The Director of Recruitment (Colonial Service), 29 Queen Anne's Gate, S.W.1 (June 22)

TEAcher of Physics at the Rugby College of Technology and Arts-The Principal and Organizer of Further Education in Rugby 61 Clifton Road, Rugby.

TEMPORARY GRADUATE ASSISTANT (MAN or WOMAN) to teach Physics at the County Technical College, Dartford-F. L. Notley, 11 Essex Road, Dartford. 